\title{
Hubungan Kadar Serum Kuprum dengan Fungsi Fagositosis Neutrofil pada Anak Leukemia Limfositik Akut
}

\author{
Astri Pinilih, Bambang Sudarmanto \\ Departemen Ilmu Kesehatan Anak Fakultas Kedokteran Universitas Diponegoro/Rumah Sakit Dr. Kariadi, Semarang
}

Latar belakang. Leukemia merupakan keganasan sel darah yang berasal dari sumsum tulang. Defek kualitatif neutrofil seperti kelainan kemotaksis, fagositosis dan migrasi neutrofil terjadi pada leukemia. Kuprum adalah mikronutrien yang berperan dalam fungsi neutrofil dan makrofag. Penurunan jumlah neutrofil dan gangguan fungsi neutrofil dikaitkan dengan defisiensi kuprum.

Tujuan. Mengetahui hubungan kadar serum kuprum dengan fungsi fagositosis neutrofil pada anak leukemia limfositik akut.

Metode. Penelitian observasional analitik dengan metode potong lintang pada 25 anak leukemia limfositik akut usia $1-10$ tahun di RSUP Dr. Kariadi Semarang. Kadar serum kuprum dan indeks fungsi fagositosis diukur dan dianalisis dengan menggunakan korelasi Pearson.

Hasil. Dua puluh lima anak yang memenuhi kriteria, terdiri dari 18 lelaki (72\%) dan 7 perempuan (28\%). Status gizi terdiri dari status gizi baik 12 anak (48\%) dan malnutrisi 13 anak (52\%). Fase kemoterapi terbanyak adalah induksi dan konsolidasi pada 17 anak $(68 \%)$. Rerata kadar serum kuprum normal yaitu 1254,8 $(464,77) \mu \mathrm{g} / \mathrm{L}$. Rerata indeks fagositosis neutrofil menurun yaitu 53,08 (20)\%. Tidak terdapat hubungan kadar serum kuprum dengan fungsi fagositosis neutrofil pada anak leukemia limfositik akut ( $\mathrm{p}=0,364)$ Kesimpulan. Rerata indeks fagositosis neutrofil rendah pada anak leukemia limfositik akut dibandingkan nilai normal. Rerata kadar serum kuprum normal pada anak leukemia limfositik akut. Tidak terdapat hubungan kadar serum kuprum dengan fungsi fagositosis neutrofil pada anak leukemia limfositik akut. Sari Pediatri 2018;20(4):197-201

Kata kunci: leukemia, serum kuprum, fungsi fagositosis neutrofil

\section{Correlation between Serum Copper Level and Neutrophil Phagocytic Function in Children with Acute Lymphocytic Leukemia}

Astri Pinilih, Bambang Sudarmanto

Background. Leukemia is hematologic malignancy that originates in the bone marrow. Qualitative abnormalities of neutrophils function including chemotaxis, phagocytosis and migration are found in leukemia. Copper is a micronutrient that plays a role on neutrophil and macrophage function. Copper deficiency is associated with decreased neutrophil count and impaired neutrophil function. Objective. To determine the correlation between serum copper level and neutrophil phagocytic function in children with acute lymphocytic leukemia.

Method. Analytic observational study with cross sectional method was conducted to 25 acute lymphocytic leukemia children aged 1-10 years in Kariadi Hospital Semarang. Serum copper level and phagocytic index of neutrophil were measured and statistical analysis was performed using Pearson correlation.

Result. Twenty five children matched the criteria, consisted of 18 males (72\%) and 7 females (28\%). 12 children (48\%) had good nutritional status and 13 children were malnourished (52\%). The mean of serum copper level was normal 1254.8(464.77) $\mu \mathrm{g} /$ L. The mean of phagocytic index of neutrophil was decreased 53(20)\%. There was no association of serum copper level and phagocytic index of neutrophil function in children with acute lymphocytic leukemia.

Conclusion. The mean of phagocytic index of neutrophil in children with acute lymphocytic leukemia was lower than normal value. The mean of serum copper level was normal in children with acute lymphocytic leukemia. There was no correlation between serum copper levels and neutrophil phagocytic function in children with acute lymphocytic leukemia. Sari Pediatri 2018;20(4):197-201

Key words: leukemia, serum copper level, neutrophil phagocytic function

Alamat korespondensi: Astri Panilih. Departemen Ilmu Kesehatan Anak Fakultas Kedokteran Universitas Diponegoro/Rumah Sakit Dr. Kariadi Semarang. Email: astri. pie85@gmail.com 
L eukemia merupakan kanker tersering pada anak dengan jumlah kasus mencapai sepertiga dari seluruh keganasan pada anak. Leukemia merupakan penyakit keganasan sel darah yang berasal dari sumsum tulang, ditandai oleh proliferasi sel darah putih dengan manifestasi adanya sel abnormal dalam darah tepi. Angka kejadian leukemia limfositik akut (LLA) pada anak 5 kali lebih besar dibandingkan dengan leukemia mielositik akut (LMA). ${ }^{1,2}$

Infeksi merupakan salah satu etiologi mortalitas pada pasien anak dengan leukemia yang menjalani kemoterapi. Neutropenia telah diketahui merupakan faktor risiko terjadinya infeksi berat pada anak dengan leukemia. Insidensi infeksi pada pasien leukemia tanpa neutropenia semakin meningkat dikarenakan obatobatan immunosupresif. Beberapa obat kemoterapi, seperti steroid, vincristin, vinblastin, siklofosfamide dan 6-merkaptopurin berpengaruh negatif terhadap fungsi leukosit polimorfonuklear. ${ }^{3}$

Fagositosis merupakan bagian dari sistem imunitas non spesifik. Neutrofil merupakan salah satu sel yang berfungsi melakukan fagositosis terhadap bakteri, virus, dan zat berbahaya lainnya. Salah satu pengukuran fungsi fagositosis neutrofil adalah dengan metode latex, yang dinyatakan sebagai indeks fagositosis dan presentase fagositosis. Berbagai defisiensi mikronutrien dapat menyebabkan penurunan fungsi neutrofil, antara lain, defisiensi kuprum, besi, vitamin A, vitamin B12, vitamin $\mathrm{C}$, vitamin $\mathrm{E}$ serta seng. ${ }^{4}$ Tujuan penelitian ini adalah untuk mengetahui hubungan kadar serum kuprum dengan fungsi fagositosis neutrofil pada anak leukemia limfositik akut.

\section{Metode}

Jenis penelitian adalah penelitian observasional analitik dengan rancangan studi potong lintang. Penelitian ini dilakukan di Bangsal Anak Rumah Sakit Umum Pusat (RSUP) Dr. Kariadi, Semarang. Pemeriksaan darah rutin dan hitung jenis dilakukan di laboratorium Patologi Klinik RSUP Dr. Kariadi Semarang. Pemeriksaan kadar serum kuprum dilakukan di Laboratorium Prodia Semarang dengan metode pemanasan basah dari Atomic Absorbent Spectrophotometer (AAS) sedangkan fungsi fagositosis neutrofil diperiksa di Laboratorium GAKI Fakultas Kedokteran UNDIP Semarang dengan metode flow cytometry, yaitu menghitung jumlah partikel latex beads yang difagositosis.
Kriteria inklusi meliputi anak yang didiagnosis leukemia limfositik akut berusia 1-10 tahun, menjalani kemoterapi sesuai dengan protokol LLA Indonesia standart risk tahun 2015, dan orang tua bersedia ikut dalam penelitian. Kriteria eksklusi meliputi pasien yang mengalami defisiensi imun (status infeksi HIV atau menderita sindrom Down), pasien yang mengalami syok atau gangguan hemodinamik, pasien neutropenia serta pasien yang mengonsumsi suplemen yang mengandung kuprum.

Analisis deskriptif dilakukan terhadap karateristik demografi serta hasil pemeriksaan fisik dan laboratorium subyek penelitian. Uji normalitas distribusi data dilakukan dengan uji Saphiro-Wilk oleh karena besar sampel termasuk kecil ( $\mathrm{n}<50$ subyek). Hubungan antara kadar serum kuprum dengan fungsi fagositosis neutrofil dianalisis dengan uji korelasi Pearson. Nilai p dianggap bermakna apabila $\mathrm{p}<0,05$ dengan $95 \%$ interval kepercayaan.

Penelitian telah lulus kaji etik dari Komisi Etika Penelitian Kedokteran FK Undip/ RSDK No. 282/ EC/ FK-RSDK/ 2017 dan izin dari instansi terkait.

\section{Hasil}

Selama periode penelitian didapatkan 25 subyek penelitian. Subyek adalah pasien leukemia limfositik akut yang memenuhi kriteria inklusi dan eksklusi. Gambaran subyek penelitian tertera pada Tabel 1.

Tabel 1. Karateristik subyek penelitian

\begin{tabular}{lccc}
\hline Variabel & Jumlah & $\%$ & Rerata(SD) \\
\hline Usia & & & $6,88(2,71)$ \\
Jenis kelamin & & & \\
$\quad$ Laki-laki & 18 & 72 & \\
$\quad$ Perempuan & 7 & 28 & \\
$\quad$ Status gizi & & & \\
$\quad$ Baik & 12 & 48 & \\
$\quad$ Malnutrisi & 13 & 52 & \\
$\quad$ Fase kemoterapi & & & \\
$\quad$ Induksi dan konsolidasi & 17 & 68 & \\
$\quad$ Pemeliharaan & 8 & 32 & \\
$\quad$ Hemoglobin (g/dl) & & & \\
$\quad \geq 10$ & 17 & 68 & $11,18(1,96)$ \\
$\quad<10$ & 8 & 32 & \\
$\quad$ Trombosit (/UL) & & & 157272 \\
$\quad \geq 100.000$ & 12 & 48 & $(116021)$ \\
$\quad<100.000$ & 13 & 52 & \\
& & & \\
\hline
\end{tabular}


Astri Pinilih dkk: Hubungan kadar serum kuprum dengan fungsi fagositosis neutrofil pada LLA

Subyek penelitian dilakukan pengukuran kadar serum kuprum dan indeks fagositosis neutrofil. Tabel 2 menunjukkan rerata kadar serum kuprum yang normal dan indeks fagositosis neutrofil yang lebih rendah dibandingkan dengan kadar normal.

Tabel 2. Rerata kadar serum kuprum dan indeks fagositosis neutrofil

\begin{tabular}{lc}
\hline Variabel & Rerata $(\mathrm{SD})$ \\
\hline Kuprum $(\mu \mathrm{g} / \mathrm{L})$ & $1254,8(464,77)$ \\
Indeks fagositosis neutrofil $(\%)$ & $53(20)$ \\
\hline
\end{tabular}

Indeks fagositosis neutrofil dan kadar serum kuprum dilakukan uji beda dengan $t$-test independent berdasarkan jenis kelamin, status gizi, dan fase kemoterapi. Hasil tersebut tertera pada Tabel 3 dan 4.

Data kadar serum kuprum dan indeks fagositosis neutrofil berupa data numerik dengan distribusi normal, sehingga uji korelasi dilakukan dengan korelasi Pearson. Setelah diuji didapatkan bahwa kadar serum kuprum tidak memengaruhi indeks fagositosis neutrofil secara langsung dengan nilai p>0,05 (Tabel 5).

Tabel 3. Indeks fagositosis neutrofil (\%)

\begin{tabular}{lcc}
\hline Variabel & Rerata (SD) & $\mathrm{p}$ \\
\hline Jenis kelamin & & \\
$\quad$ Laki-laki & $52(19)$ & 0,568 \\
$\quad$ Perempuan & $57(24)$ & \\
Status gizi & & \\
$\quad$ Baik & $57(22)$ & 0,412 \\
$\quad$ Malnutrisi & $50(19)$ & \\
Fase kemoterapi & & \\
$\quad$ Induksi \& konsolidasi & $59(24)$ & 0,261 \\
$\quad$ Pemeliharaan & $50(16)$ & \\
\hline
\end{tabular}

Tabel 4. Kadar serum kuprum ( $\mu \mathrm{g} / \mathrm{L})$

\begin{tabular}{lcc}
\hline Variabel & Rerata (SD) & $\mathrm{p}$ \\
\hline $\begin{array}{l}\text { Jenis kelamin } \\
\text { Laki-laki }\end{array}$ & $1268,94(451,59)$ & 0,813 \\
$\quad$ Perempuan & $1218,29(533,00)$ & \\
Status gizi & & \\
$\quad$ Baik & $1193,50(373,38)$ & 0,538 \\
$\quad$ Malnutrisi & $1311,31(544,99)$ & \\
Fase kemoterapi & & \\
$\quad$ Induksi \& konsolidasi & $1095,80(599,73)$ & 0,225 \\
$\quad$ Pemeliharaan & $1254,76(464,77)$ & \\
\hline
\end{tabular}

Sari Pediatri, Vol. 20, No. 4, Desember 2018
Tabel 5. Hubungan antara kadar serum kuprum dengan indeks fagositosis neutrofil

\begin{tabular}{lcc}
\hline \multirow{2}{*}{ Variabel } & \multicolumn{2}{c}{ Indeks fagositosis neutrofil } \\
\cline { 2 - 3 } & $\mathrm{p}$ & $\mathrm{r}$ \\
\hline Kuprum & 0,364 & $-0,190$ \\
\hline
\end{tabular}

\section{Pembahasan}

Pada pasien leukemia akut terjadi gangguan produksi dan maturasi neutrofil sehingga menyebabkan kelainan fungsi dan kuantitas neutrofil. Hal ini mengakibatkan risiko infeksi tinggi. Kemoterapi juga menurunkan kemampuan fagositosis dan bakterisidal neutrofil melalui gangguan aktivitas Hexose Monophosphat Shunt. ${ }^{5,6}$

Hasil penelitian ini menunjukkan hasil indeks fagositosis neutrofil yang rendah dengan nilai rata-rata $53 \%$ dimana $92 \%$ subyek menunjukkan hasil indeks fagositosis yang rendah. Hal tersebut sejalan dengan penelitian Tanaka ${ }^{7}$ yang meneliti fungsi neutrofil pada anak leukemia limfoblastik akut. Pada penelitian tersebut oxidative burst dan aktivitas fagositosis neutrofil dianalisis menggunakan flow cytometry. Hasil penelitian ini menunjukkan gangguan oxidative burst neutrofil dengan persentase neutrofil $59 \pm 13,2 \%$ pada fase kemoterapi induksi, sedangkan pada kelompok kontrol menunjukkan hasil yang normal 93,8 $26,1 \%$. Fungsi neutrofil mengalami perbaikan pada saat pasien menjalani kemoterapi fase konsolidasi.

Penelitian Lejeune ${ }^{8}$ mengenai fungsi fagositosis neutrofil pada pasien leukemia limfositik akut menunjukkan produksi hidrogen peroksidase mengalami penurunan selama fase kemoterapi intensif dan kembali normal pada fase kemoterapi pemeliharaan. Sementara aktivitas bakterisidal melawan mikroorganisme Gram positif dan negatif mengalami penurunan selama fase kemoterapi intensif dan kembali normal setelah selesai kemoterapi.

Penelitian Ajdary ${ }^{9}$ menunjukkan gangguan aktivitas fagositik yang meliputi intracellular killing, reduksi nitro blue tetrazolium (NTB) dan fagositosis pada 37 pasien CML. Hasil penelitian menunjukkan penurunan aktivitas fagositik pada pasien CML dibandingkan kelompok kontrol. Penurunan aktivitas fagositik ini terutama terjadi pada fase blastik dan mengalami perbaikan dengan nilai aktivitas fagositik yang normal pada fase remisi.

Kuprum dapat berfungsi sebagai suatu anti 
oksidan dan pro oksidan. Sebagai antioksidan, kuprum menetralisasi radikal bebas dan mencegah kerusakan yang timbul akibat radikal bebas, sedangkan sebagai pro oksidan, kuprum mendukung terjadinya radikal bebas. ${ }^{10}$

Hasil penelitian ini menunjukkan rata-rata kadar serum kuprum yang normal, yaitu 1254,8 ug/L. Pada penelitian yang dilakukan oleh Higuchi dkk ${ }^{11}$ melaporkan adanya antibodi anti neutrofil pada pasien dengan defisiensi kuprum, yang menunjukkan adanya mekanisme kehilangan neutrofil. Selain terjadi penurunan jumlah neutrofil dalam sirkulasi darah, juga terjadi gangguan fungsi neutrofil. Adanya penurunan produksi anion superoksida dan aktivitas kandidasidal disebabkan karena defisiensi kuprum.

Kuprum mempunyai peran esensial dalam beberapa reaksi enzimatik sel darah merah. Defisiensi kuprum akan memengaruhi transportasi dan utilisasi besi, sintesis heme serta pembentukan seruloplasmin. ${ }^{12}$ Pada tahun 2002, penelitian Gregg dkk ${ }^{13}$ menjelaskan pasien dengan sindrom mielodisplasia yang dilakukan transplantasi sumsum tulang, terjadi defisiensi kuprum yang berat. Setelah dilakukan pemberian kuprum, abnormalitas hematologi dan morfologi sumsum tulang mengalami perbaikan.

Penelitian yang dilakukan oleh Dayer dkk, ${ }^{14}$ mengenai kadar serum kuprum pada pasien leukemia dan limfoma, menunjukkan peningkatan kadar serum kuprum secara bermakna dibandingkan dengan anak yang sehat. Hal tersebut mengindikasikan adanya peran kuprum dalam proses keganasan. Peningkatan kadar serum kuprum akan meningkatkan peroksidase lemak, destruksi sistem antioksidan serta radikal hidroksil yang menyebabkan mutasi DNA. Kuprum merupakan komponen struktur katekolamin yang merupakan endothelial growth factor sehingga dapat menyebabkan angiogenesis tumor.

Hasil penelitian dapat dipengaruhi oleh fase kemoterapi dan status gizi pasien. Penelitian Sgarbieri $\mathrm{dkk}^{15}$ yang membandingkan kadar serum zink dan kuprum pada saat terdiagnosis leukemia dan pada saat terapi sitostatika menunjukkan adanya perbedaan. Pada saat terdiagnosis leukemia, kadar rata-rata serum zink dalam batas normal $(100,8 \pm 25 \mu \mathrm{g} / \mathrm{dl})$, sedangkan kadar rata-rata serum kuprum meningkat di atas normal $(206 \pm 75) \mu g / d l$. Pada saat menjalani kemoterapi, kadar serum zink tidak mengalami perbedaan bermakna, sedangkan kadar serum kuprum menurun pada saat kemoterapi fase induksi dan stabil pada saat fase konsolidasi serta pemeliharaan. Tidak ada perbedaan kadar serum zinc dan cuprum yang signifikan antara grup leukemia standart risk dan high risk.

Penelitian mengenai kadar serum zink dan kuprum pada anak dengan status gizi malnutrisi dan baik menunjukkan bahwa rerata kadar serum zink dan kuprum mengalami penurunan pada kelompok anak dengan status gizi malnutrisi dibandingkan dengan kelompok kontrol. Mikronutrien seperti zink dan kuprum diperlukan dalam metabolisme tubuh dan pertumbuhan sehingga suplementasi mikronutrien direkomendasikan dalam tatalaksana malnutrisi. ${ }^{12}$

Kuprum diketahui mempunyai peran penting dalam perkembangan sistem imun. Defisiensi kuprum menurunkan efektivitas respon imun didapat. Selain itu, defisiensi kuprum juga dihubungkan dengan neutrofil dan makrofag. Pasien dengan defisiensi kuprum terjadi penurunan fungsi neutrofil, yaitu gangguan sirkulasi, perlekatan ke endothelium, dan aktivasi oxidative burst. Defisiensi kuprum menyebabkan penurunan diferensiasi, maturase, dan proliferasi leukosit sehingga dapat menyebabkan penurunan kuantitas neutrofil. ${ }^{15,16}$ Pada penelitian kami didapatkan hasil serum kuprum yang normal, tetapi indeks fagositosis neutrofil mengalami penurunan. Hal tersebut terkait dengan kemoterapi yang dijalani oleh pasien.

Hasil penelitian menunjukkan tidak ada hubungan kadar serum kuprum dengan fungsi fagositosis neutrofil pada pasien LLA. Penelitian mengenai kadar serum kuprum dan fungsi fagositosis neutrofil pada manusia masih terbatas. Kuprum merupakan mineral yang berperan dalam regulasi mettaloenzyme superoxide dismutase dalam sistem imunitas, respon sel limfosit $\mathrm{T}$ dan B mengalami gangguan pada defisiensi kuprum. ${ }^{17}$ Penelitian Hopskin ${ }^{19}$ menunjukkan penurunan sintesis IL2 yang diaktivasi oleh sel $\mathrm{T}$ pada pasien dengan defisiensi kuprum. ${ }^{18}$ Penelitian Munoz ${ }^{20}$ menganalisis efek terapi kuprum dan fagositosis neutrofil pada bayi dengan defisiensi kuprum. Suplementasi kuprum diberikan melalui susu formula $(40 \mu \mathrm{g} / \mathrm{kgBB})$ selama 1 bulan. Kadar serum kuprum, seruloplasmin dan aktivitas fagositik diukur sebelum dan setelah terapi. Hasil penelitian menunjukkan perbaikan kadar serum kuprum, seruloplasmin dan aktivitas fagositik setelah terapi.

Keterbatasan penelitian ini adalah tidak ada grup kontrol untuk membandingkan antara kadar serum kuprum dan indeks fungsi fagositosis neutrofil pada 
anak yang sehat. Selain itu, fungsi fagositosis neutrofil dapat dipengaruhi oleh faktor lain seperti infeksi dan tidak dilakukan food recall untuk memperhitungkan kadar serum kuprum dari faktor asupan nutrisi. Penelitian ini tidak meneliti mengenai faktor-faktor yang dapat memengaruhi fungsi fagositosis neutrofil seperti mikronutren selain kuprum, imunofenotif sel leukemia, translokasi kromosom, variasi genetika pasien serta jumlah sampel yang sedikit.

\section{Kesimpulan}

Rerata indeks fagositosis neutrofil rendah pada anak leukemia limfositik akut dibandingkan nilai normal. Rerata kadar serum kuprum normal pada anak leukemia limfositik akut. Tidak terdapat hubungan kadar serum kuprum dengan fungsi fagositosis neutrofil pada anak leukemia limfositik akut.

\section{Daftar pustaka}

1. Permono B,Ugrasena IDG. Leukemia akut. Dalam: Permono B, Sutaryo, Ugrasena IDG,Windiastuti E, Abdulsalam M, penyunting. Buku ajar hematologi onkologi anak. Edisi Pertama. IDAI; 2005.h.236-47.

2. Launder TM, Lawnicki LC, Perkins ML. Introduction to leukemia and the acute leukemia. Dalam: Harmening DM, penyunting. Clinical hematology and fundamental of hemostasis edisi ke-4. Philadelphia: FA. Davis Company; 2002.h.272-357.

3. Chandran R, Hakki M, Spurgeon S. Infections in leukemia. In Tech 2012;17:1-36.

4. Erickson KL, Medina EA, Hubbard NE. Micronutrient and innate immunity. JID 2000;182:5-10.

5. Borregaard N. Neuthropils, from marrow microbes. Immunity 2010;33:657-70.

6. Nathan DG, Oski AF. Phagocyte system. Dalam: Nathan DG, Oski AF, penyunting. Hematology of Infancy and Childhood. Edisi ke-15. Philadelphia: Lippincott Williams and Walkins; 2001.h.1239-45.
7. Tanaka F, Goto H, Yokosuka T, Yanagimachi M, Kajiwara R. Supressed neutrophil function in children with acute lymphoblastic leukemia. Int J Hematol 2009;90:311-7.

8. Lejeune M, Ferster A, Cantinieauz B, Sariban E. Prolonged but reversible neutrophil dysfunctions differentially sensitive to granulocyte colony stimulating factor in children with acute lymphoblastic leukemia. Br J Haematol 1998;102:1284-91.

9. Ajdary S, Hamidpoor L, Zandieh T. Function of neutrophils in different phases of chronic myelogenous leukemia. Iran Biomed J 2002;6:83-8.

10. Nava JO, Gomez YG, Aguiar BI, Vazquez MA. Survival of patients with acute lymphoblastic leukemia. Dalam: Mejia JM, Arangure, penyunting. Clinical epidemiology of acute lymphoblastic leukemi. Mexico: Intech; 2013.h.237-63.

11. Higuchi S, Higashi A, Nakamura T, Yanabe Y, Matsuda I. Anti-neutrophil antibodies in patients with nutritional copper deficiency. Eur J Pediatr 2001;150:327-30.

12. Ugwuja EI, Nwosu KO, Ugwu NC, Okonji M. Serum zinc and copper levels in malnourished pre school age children in Jos, North Central Nigeria. Pak J Nutr 2007;6:349-54.

13. Gregg XT, Reddy V, Prchal JT. Copper deficiency masquerading as myelodysplastic syndrome. Blood 2002;100:1493-5.

14. Dayer D, Asadi ZT, Samie M, Reisiyan N, Kalantarian G, Vakhshiteh F. Evaluation of serum copper levels in patient with leukemia and lymphoma. N Y Sci J 2015;8:102-5.

15. Sgarbieri UR, Fisberg M, Tone LG, Latorre MRD. Nutritional assessment and serum zinc and copper concentration among children with acute lymphocytic leukemia : a longitudinal study. Sao Paulo Med J 2006; 124:316-20.

16. Djoko KY, Ong CL, Walker MJ, McEwan AG. Copper and zinc toxicity and its role in innate immune defense against bacterial pathogens. JBC 290:18954-61.

17. Bonham M, O'Connor JM, Hannigan BM, Strain JJ. The immune system as a phsiological indicator of marginal copper status. Br J Nutr 2002;87:393-403.

18. Ibrahim KS, El Sayed EM. Potential role of nutrients on immunity. Br J Nutr 2016;23:464-74.

19. Hopkins RG, Failla ML. Transcriptional regulation of interleukin-2 gene expression is impaired by copper deficiency in Jurkat human T lymphocytes. J Nutr 1999;129:596-601.

20. Munoz C, Rios E, Olivos J, Brunser O, Olivares M. Iron, copper and immunocompetence. Br J Nutr 2007;98:S24-8. 